\title{
Site surveys related to Expedition $310^{1}$
}

\author{
Expedition 310 Scientists, $^{2}$ B. Hamelin, ${ }^{3}$ and G. Lericolais ${ }^{4}$
}

\section{Chapter contents}

Previous surveys around Tahiti . ........ 1

SISMITA ..................

References..................

Figures................

${ }^{1}$ Expedition 310 Scientists, 2007. Site surveys related to Expedition 310. In Camoin, G.F., Iryu, Y., Mclnroy, D.B., and the Expedition 310 Scientists. Proc. IODP, 310: Washington, DC (Integrated Ocean Drilling Program Management International, Inc.). doi:10.2204/ iodp.proc.310.102.2007

2Expedition 310 Scientists' addresses. ${ }^{3}$ CEREGE, CNRS, UMR 6635, BP 80, Aix-enProvence Cedex 4, France. ${ }^{4}$ IFREMER, DRO/GM, BP 70, F-29280 Plouzane Cedex, France.

\section{Previous surveys around Tahiti}

Before the Sismique Haute Resolution, Bathymetrie et Dragages sur les Pentes Externes des Recifs de Tahiti (SISMITA) cruise in October 2002 (Camoin et al., 2003), bathymetric seafloor mapping and seismic lines at depths $>250 \mathrm{~m}$ were carried out on the northern side of Tahiti by the Washington in 1982 and SeaBeam data were collected during the Energie Thermique des Mers (ETM) 19 cruise in 1983-1987 (the Jean Charcot) (Voisset, 1990). Available data at depths $>500 \mathrm{~m}$ around the island include bathymetric and acoustic data collected during the Zone Economique de Polynésie Française (ZEPOLYF; the Atalante) (Sichoix and Bonneville, 1996) and Mission POLYDRAG1, dragage de roches sur la zone ZEPOLYF1 (Bonneville et al., 1998), oceanographic cruises, whereas previous data at depths $<250 \mathrm{~m}$ were restricted to bathymetric data around Papeete (i.e., in the vicinity of the Faaa drilling sites) (Institut Français de Recherche pour l'Exploitation de la Mer [IFREMER] and Service Hydrographique et Océanographique de la Marine [SHOM]).

\section{SISMITA}

The SISMITA cruise was carried out on 18-24 October 2002, using the Alis, owned by the Institut de Recherche pour le Développement (IRD). Shipboard participants included G. Camoin (Centre National de la Recherche Scientifique-Centre Européen de Recherche et d'Enseignement de Géosciences de l'Environnement [CNRS-CEREGE]), G. Cabioch (IRD), B. Hamelin (CEREGE), and G. Lericolais (IFREMER). During this cruise, high-resolution seismic and multibeam bathymetric data were acquired at depths ranging from 50 to $250 \mathrm{~m}$ around Tahiti, especially in the three proposed drilling areas: Faaa (proposed Site TAH-01A), Tiarei (proposed Site TAH-02A), and Maraa (proposed Site TAH-03A). The major objectives were the following:

- To determine the thickness and geometry of the last deglacial (late Pleistocene-Holocene) reef sequence and, if possible, the underlying carbonate units;

- To identify unconformities in the carbonate units overlying the volcanic basement;

- To evaluate transitional patterns between the outer reef slope and the downslope environments; and 
- To determine the morphology of the volcanic substrate.

The preliminary results of that cruise have been assembled in a report (Camoin et al., 2003).

Accurate navigation information was obtained using Global Positioning System (GPS). Other information regarding water currents was also acquired.

Multibeam data (Simrad EM 1002-100 kHz) were acquired all around Tahiti and Moorea at depths ranging from 30-40 to 500-700 m. The three target zones in Tahiti were mapped in detail: offshore Faaa (Fig. F1), Tiarei (Fig. F2), and Maraa (Fig. F3).

High-resolution seismic (IFREMER seismic equipment: asynchronic Tres Haute Resolution [THR] seismic, sediment sounder, and sparker) data were collected in the three target zones in water depths ranging from 40 to $500 \mathrm{~m}$ (Faaa, Fig. F4; Tiarei, Fig. F5; Maraa, Fig. F6). Seismic data were acquired along lines longitudinal and perpendicular to the axis of the barrier reef and within grids with dimensions of $6 \mathrm{~km} \times 1 \mathrm{~km}$ (Tiarei area), $8.5 \mathrm{~km} \times 1 \mathrm{~km}$ (Faaa area), and $9 \mathrm{~km} \times 1 \mathrm{~km}$ (Maraa area). Seismic lines are located at a minimal distance of $250 \mathrm{~m}$ from the barrier reef, and the distance between the lines forming the grid were fixed to $200-400 \mathrm{~m}$ in order to crosscut the proposed drilling sites. All potential drilling target zones were covered by crossing seismic lines. The positions of the actual holes cored during Expedition 310 are indicated on the seismic lines in Figures F4, F5, and F6.

A total of 120 seismic lines were shot in the three target zones. In several lines, the hard bottom over most of the outer shelf inhibited subbottom penetration, rendering interpretation of recorded data problematic, although some internal structure is revealed. This illustrates the difficulty of imaging drilling targets in reef environments.

The morphology of the forereef slope as obtained from echo sounder and seismic profiling exhibits consistent features around Tahiti, especially in the three drilling target zones, although the relative importance of features differs from site to site, suggesting a complex history of reef growth and drowning.

\section{Mapped morphological features}

The most significant morphological features were imaged, mapped, and ground-truthed by a series of dredgings (38 in total) on reef terraces, drowned reefs, and slopes at depths ranging from 50 to $500 \mathrm{~m}$ (Camoin et al., 2003, 2006).

\section{Terraces}

The extensive terrace recorded at 50-60 m water depth is characterized by the presence of buildups that are interpreted as relict reefs. The terrace is generally gently inclined seaward down to $90 \mathrm{~m}$.

A narrower terrace typically characterizes depths ranging from 75 to $90-100 \mathrm{~m}$. It displays abundant buildups that are interpreted as drowned reefs. On the eastern side of the island, the Tiarei area is characterized by the presence of two ridges with heights ranging from $30 \mathrm{~m}$ (base at 100 meters below sea level [mbsl]; top at $70 \mathrm{mbsl}$ ) to $45 \mathrm{~m}$ (base at 90 mbsl; top at $45 \mathrm{mbsl}$ ). In all regions, there is a clear break in slope at 90-100 mbsl where the slope steepens sharply to form a cliff.

The presence of two prominent terraces off Papeete, at 50-60 and 90-100 $\mathrm{m}$ water depths, was already demonstrated by Salvat et al. (1985) during a survey by the submersible Cyana and confirmed by relevant bathymetric data obtained from the Port Autonome de Papeete, SHOM, and IFREMER.

\section{Slope}

The transition zone between 90-100 and 200-250 m water depths may correspond either to an almost vertical wall $\left(75^{\circ}-90^{\circ}\right)$ or to a steep slope. A significant break in slope has been observed at 120-130 m water depth. This zone generally comprises laterally discontinuous ledges and gives the appearance of being highly stratified to a depth of $200 \mathrm{~m}$. Buildups as high as $45 \mathrm{mbsl}$ (base at $135 \mathrm{mbsl}$; top at $90 \mathrm{mbsl}$ ) occur locally on the slope.

A major reflector, possibly corresponding to the top of the volcanic basement, has been imaged from 120 to $150 \mathrm{~m}$ water depth close to the cliff, up to $80 \mathrm{~m}$ below the $60 \mathrm{~m}$ terrace.

\section{Dredgings}

Dredgings carried out on the successive reef terraces and slopes at depths ranging from 50 to $500 \mathrm{~m}$ yielded reef material including coral colonies and fragments, coralline algal encrustations, and microbialite crusts. Samples dredged around Tahiti have been the subject of a detailed sedimentological and chronological study (Camoin et al., 2006). In this volume, all ages are given in calendar years before present (cal. y BP), providing that U-series dates are considered as equivalent to calendar ages.

Datable material has been obtained from all depths within the bathymetric range involved in development of the last deglacial reef sequence (i.e., to 150 $\mathrm{m}$ below the present sea surface).

Ages obtained from corals dredged in the 100-120 m depth interval range from $13,123 \pm 64$ to $15,052 \pm 91$ cal. y BP (Camoin et al., 2006) and are in good agreement with those obtained from the base of the cores from holes drilled on the Papeete barrier reef $(13,750$ 
and 13,850 cal. y BP at 85 and $88 \mathrm{~m}$ below the reef surface, respectively) (Bard et al., 1996; Montaggioni et al., 1997; Camoin et al., 1999; Cabioch et al., 1999).

Most of the corals recovered within the $200-250 \mathrm{~m}$ depth interval provide very young ages $(<1000 \mathrm{cal}$. y $\mathrm{BP})$, indicating that they were more recently transported from a shallower landward phase of reef growth (Camoin et al., 2006).

\section{References}

Bard, E., Hamelin, B., Arnold, M., Montaggioni, L., Cabioch, G., Faure, G., and Rougerie, F., 1996. Deglacial sea-level record from Tahiti corals and the timing of global meltwater discharge. Nature (London, U. K.), 382:241-244. doi:10.1038/382241a0

Bonneville, A., Clovard, V., and Labrosse, S., 1998. Mission POLYDRAG1, Rapports du Programme ZEPOLYF, 2:20. Universite Francaise du Pacific, Tahiti, Polynesia Francaise.

Cabioch, G., Camoin, G.F., and Montaggioni, L.F., 1999. Postglacial growth history of a French Polynesian barrier reef tract, Tahiti, central Pacific. Sedimentology, 46(6):985-1000. doi:10.1046/j.13653091.1999.00254.x

Camoin, G.F., Gautret, P., Montaggioni, L.F., and Cabioch, G., 1999. Nature and environmental significance of microbialites in Quaternary reefs: the Tahiti paradox.
Sediment. Geol., 126(1-4):271-304. doi:10.1016/S00370738(99)00045-7

Camoin, G.F., Cabioch, G., Hamelin, B., and Lericolais, G., 2003. Rapport de mission SISMITA. Institut de recherche pour le développement, Papeete, Polynesia Francaise.

Camoin, G., Cabioch, G., Eisenhauer, A., Braga, J.-C., Hamelin, B, and Lericolais, G., 2006. Environmental significance of microbialites in reef environments during the last deglaciation. Sediment. Geol., 185(3-4):277-295. doi:10.1016/j.sedgeo.2005.12.018

Montaggioni, L.F., Cabioch, G., Camoin, G.F., Bard, E., Ribaud Laurenti, A., Faure, G., Déjardin, P., and Récy, J., 1997. Continuous record of reef growth over the past 14 k.y. on the mid-Pacific island of Tahiti. Geology, 25(6):555-558. doi:10.1130/00917613(1997)025<0555:CRORGO>2.3.CO;2

Salvat, B., Sibuet, M., and Laubier, L., 1985. Benthic megafauna observed from the submersible Cyana on the forereef slope of Tahiti (French Polynesia) between 70 and 100 m. Proc. Int. Coral Reef Symp., 5th, 2:338.

Sichoix, L., and Bonneville, A., 1996. Prediction of bathymetry in French Polynesia constrained by shipboard data. Geophys. Res. Lett., 23(18):2469-2472. doi:10.1029/96GL02122

Voisset, M., 1990. Campagne ETM 19. Coll. Tour du Monde du Jean Charcot. Oceanol. Acta, 10:238-242.

Publication: 4 March 2007 MS 310-102 
Figure F1. Swath bathymetry and seismic lines. A. Faaa area. B. Proposed Sites TAH-01A 1 to 6.

A

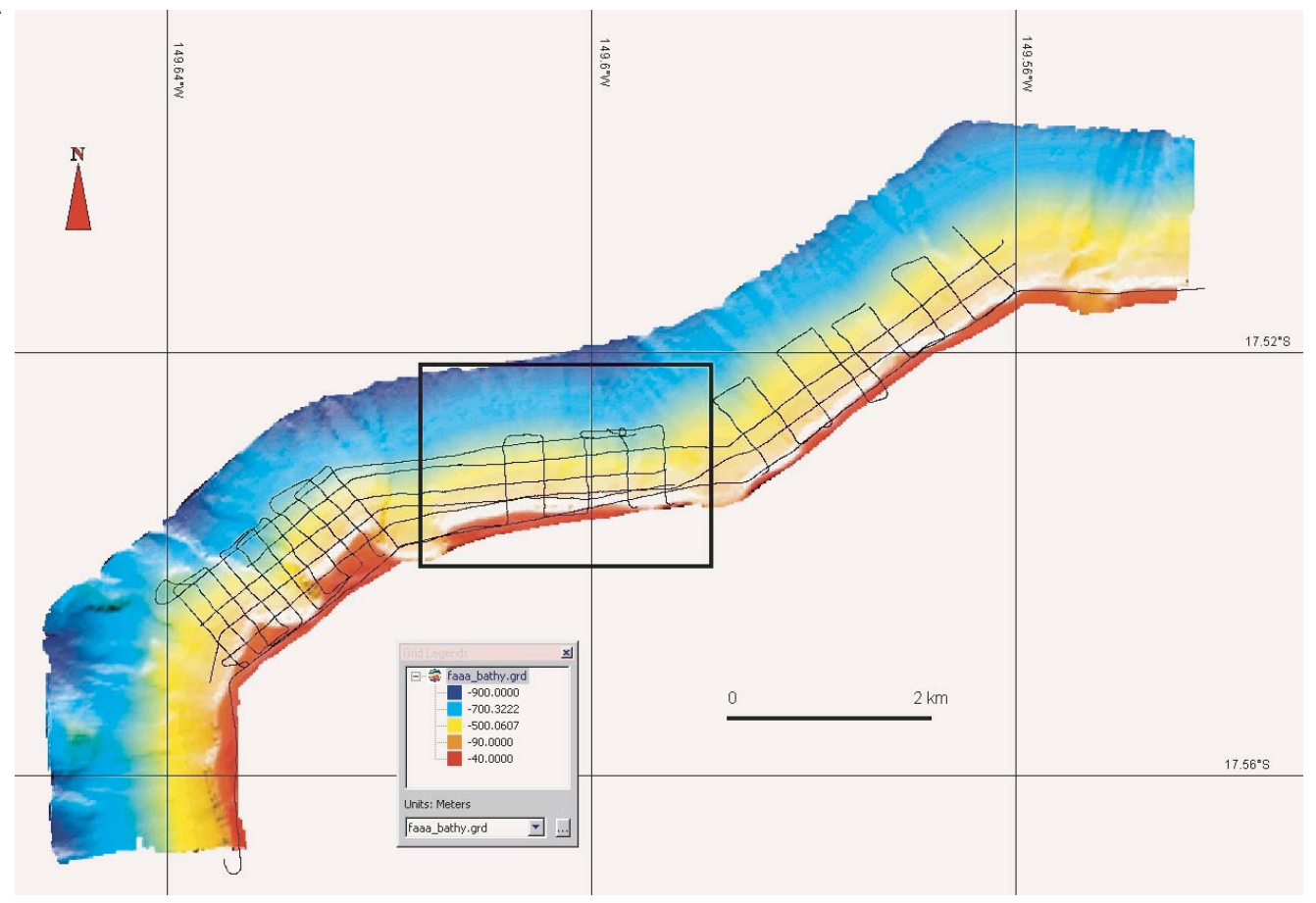

B

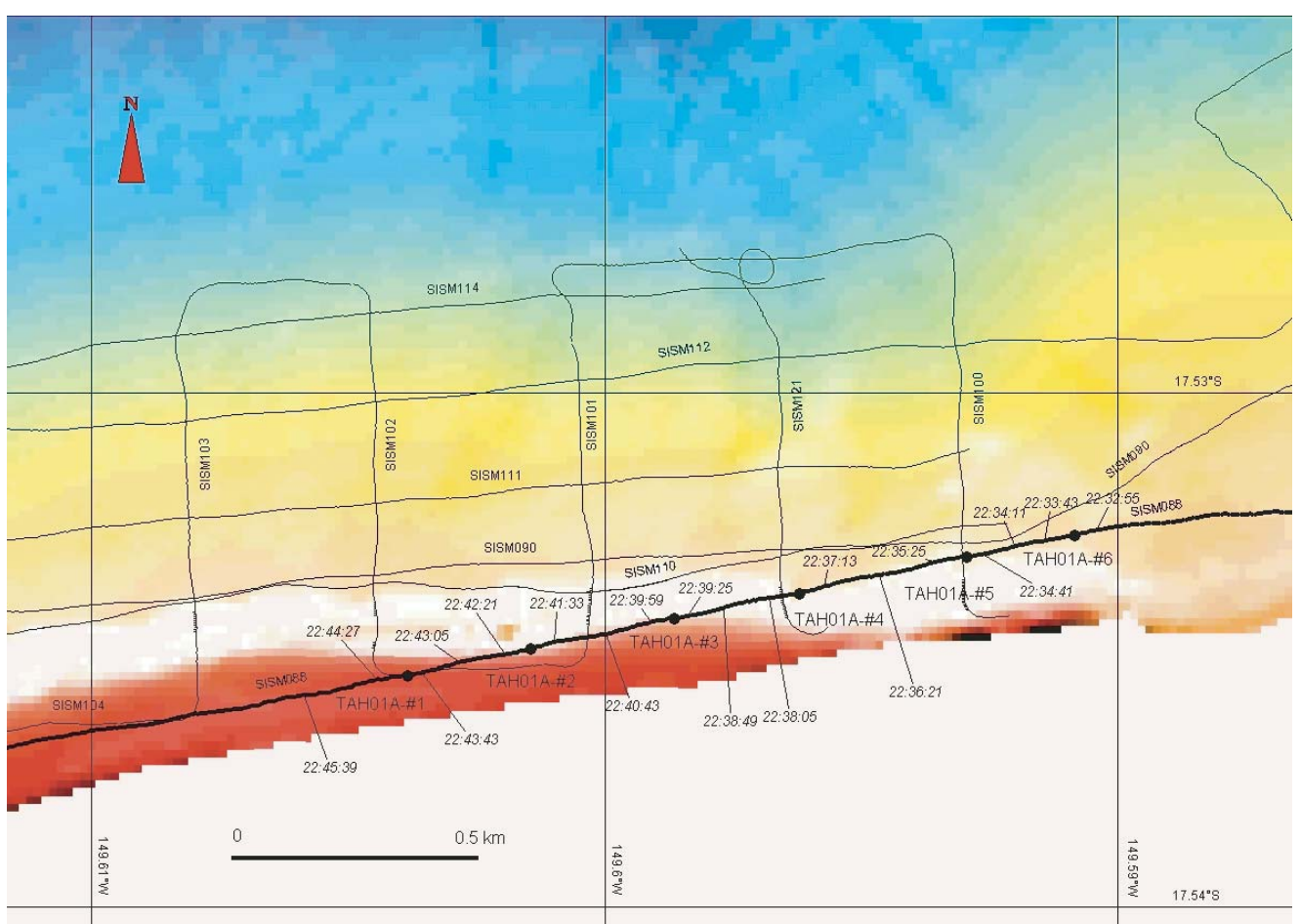


Figure F2. Swath bathymetry and seismic lines. A. Tiarei area. B. Proposed Sites TAH-02A 1 to 7.

A

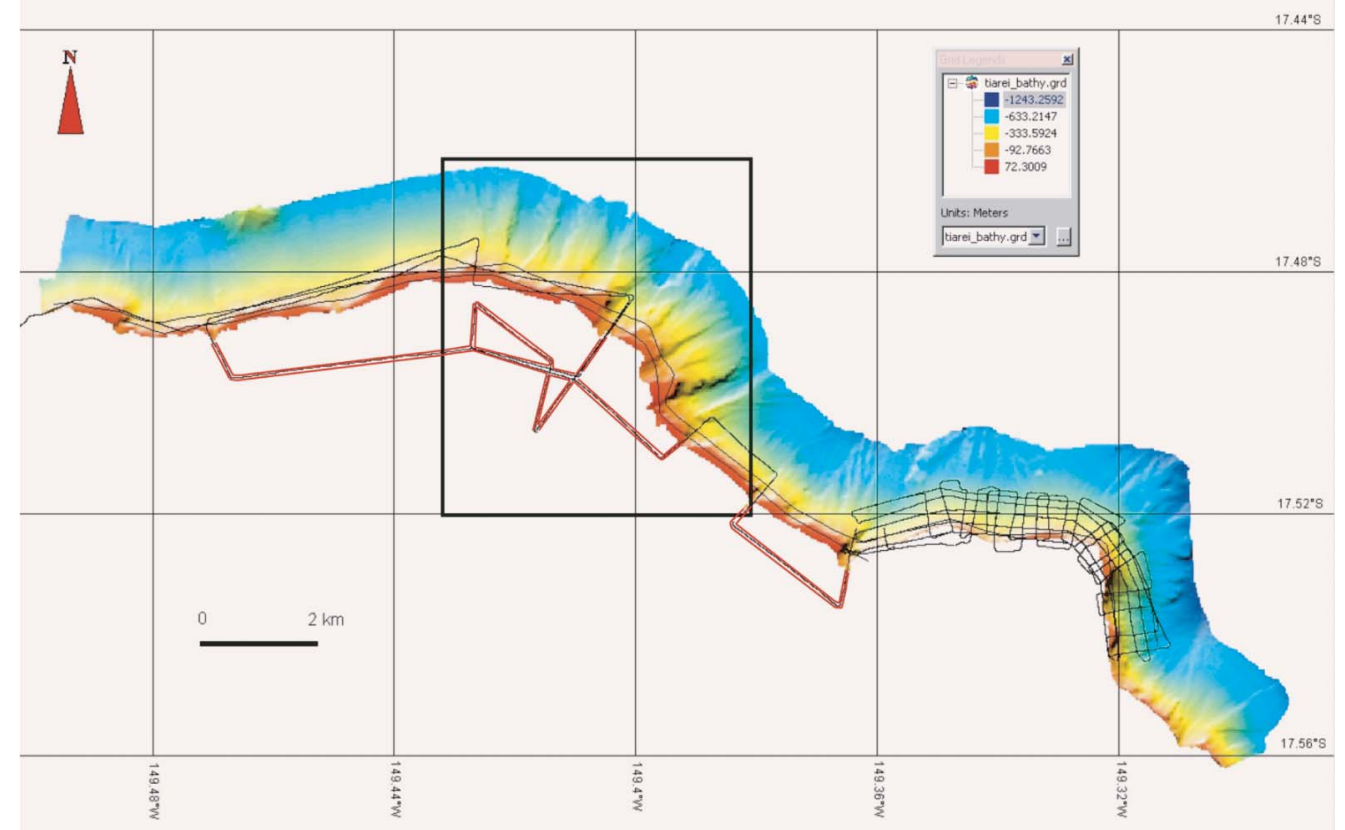

B

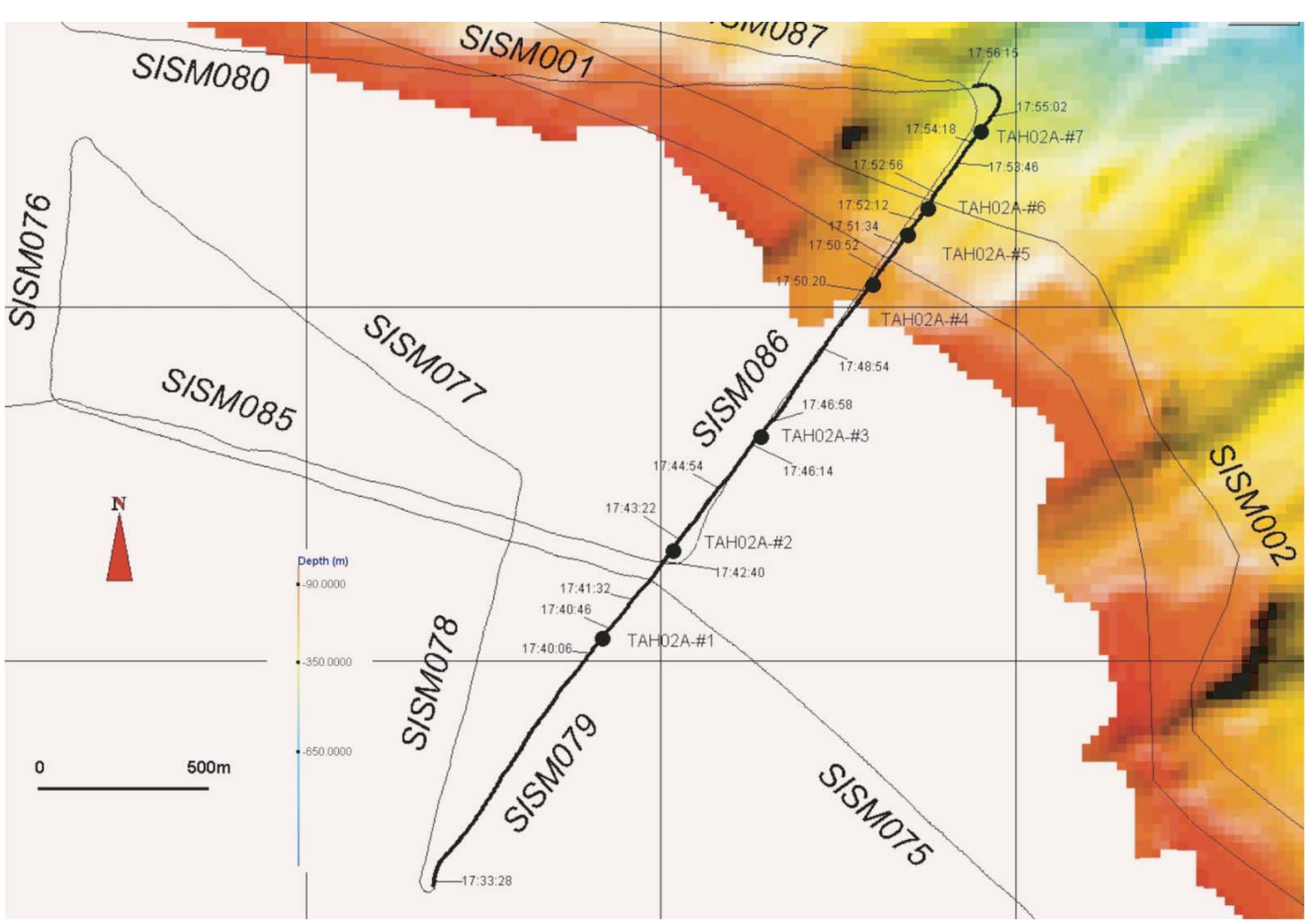


Figure F3. Swath bathymetry and seismic lines. A. Maraa area. B. Proposed Sites TAH-03A 1 to 6.

A

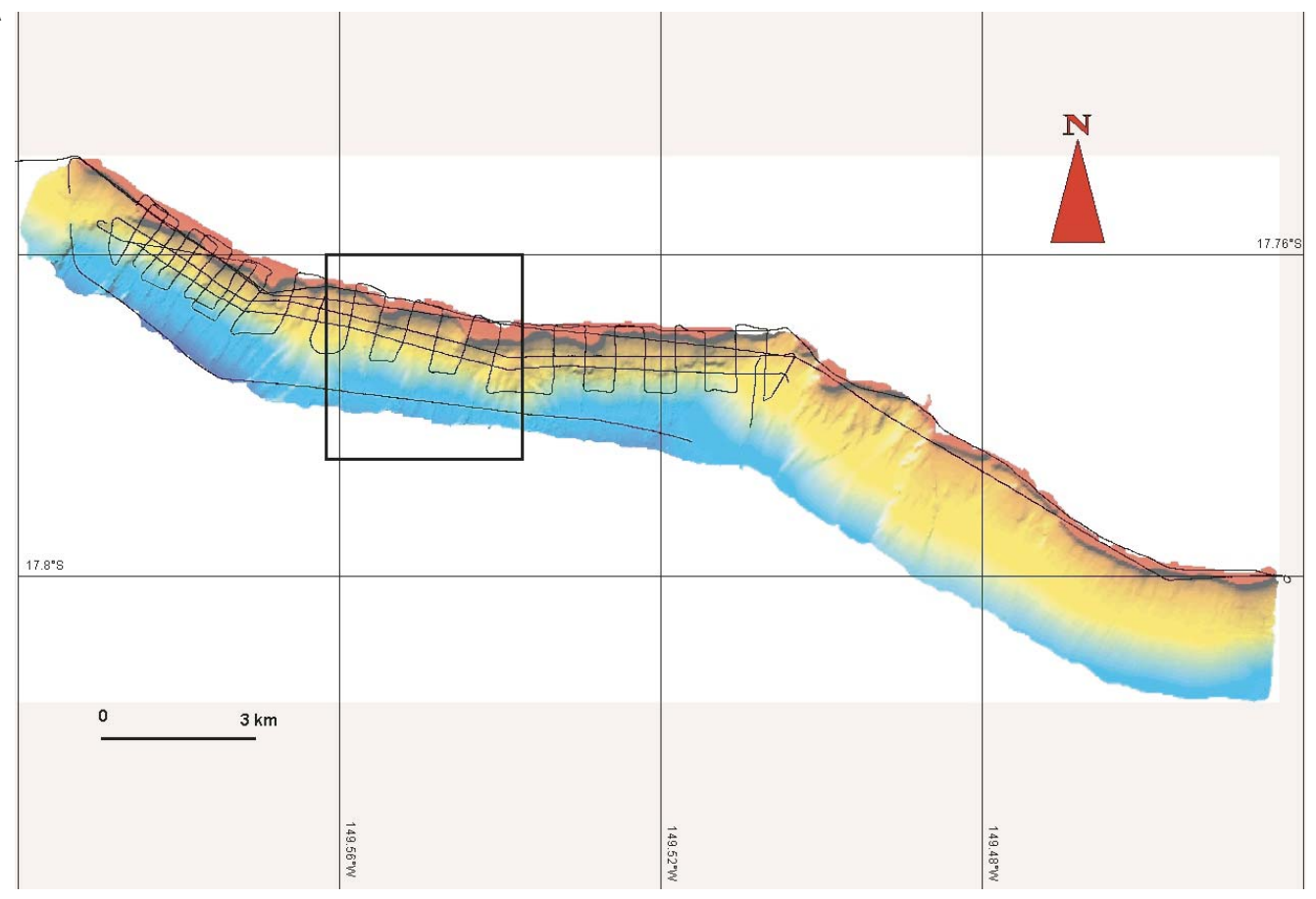

B

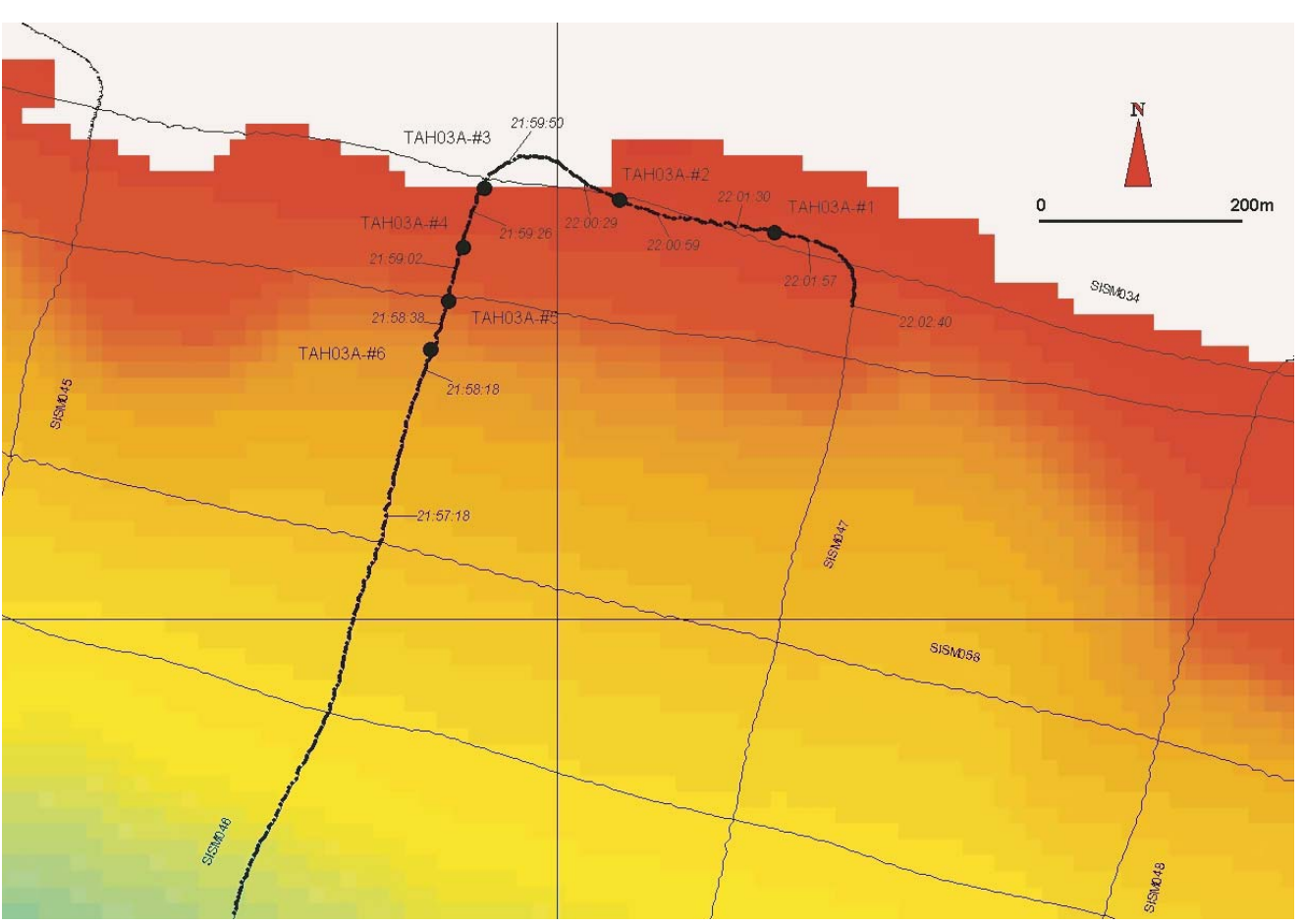


Figure F4. Seismic Line SISM 088 (Faaa) showing locations of proposed sites (red) and actual sites (black). Dashed lines indicate site is located offsection.

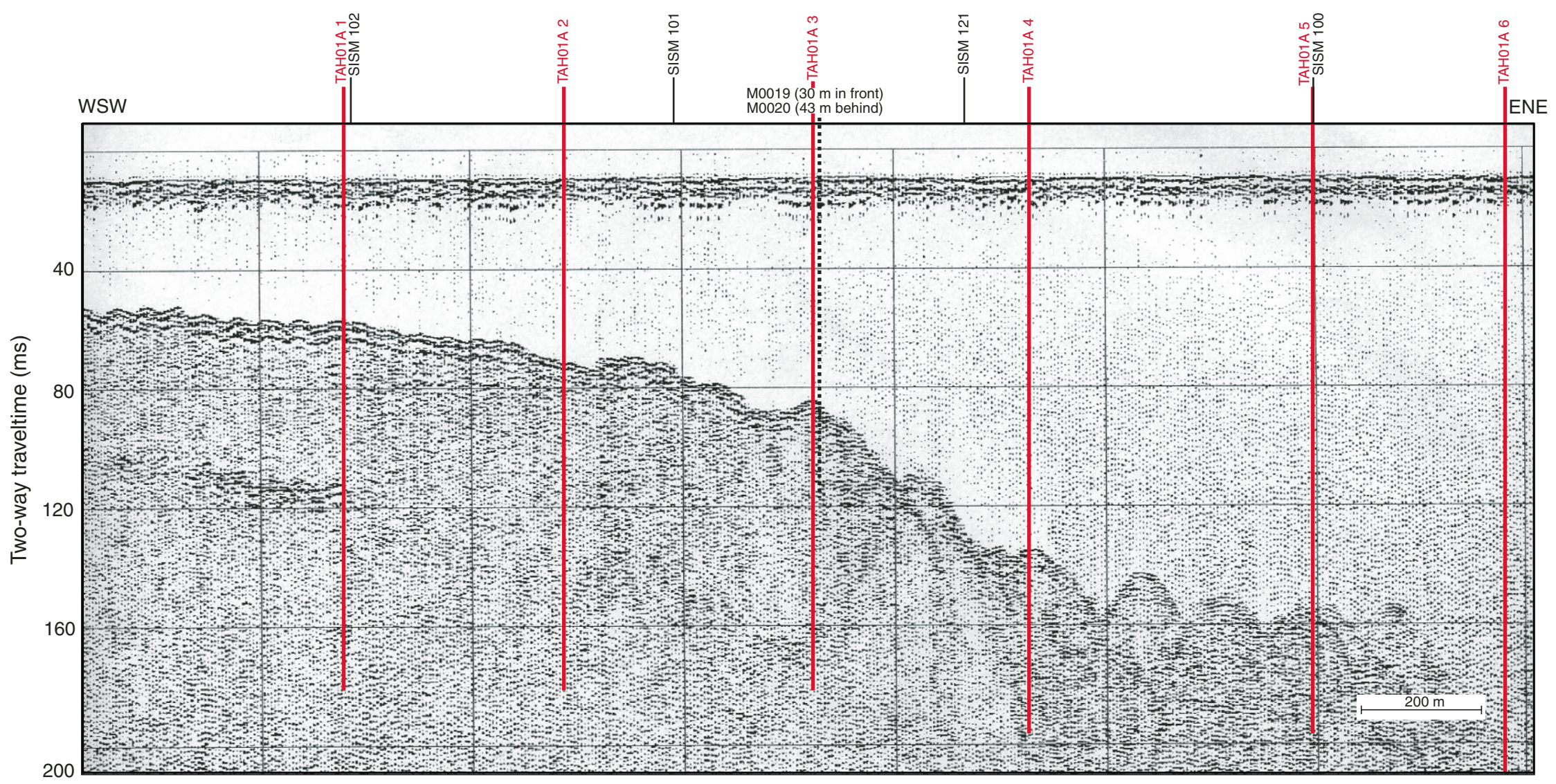


Figure F5. Seismic Line SISM 079 (Tiarei) showing locations of proposed sites (red) and actual sites (black). Dashed lines indicate site is located off-section.

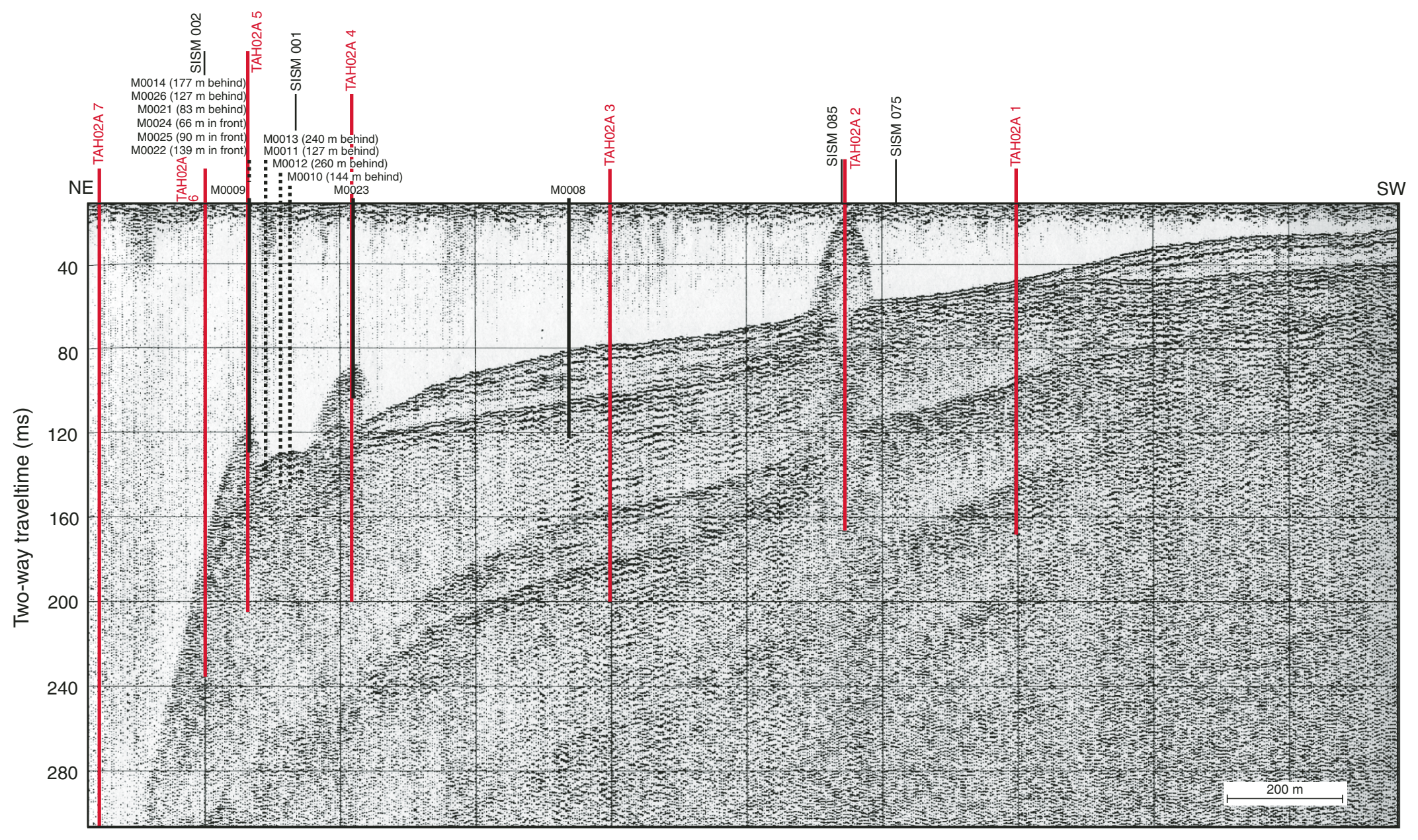


Figure F6. Seismic Line SISM 046 (Maraa) showing locations of proposed sites (red) and actual sites (black). Dashed lines indicate site is located off-section.

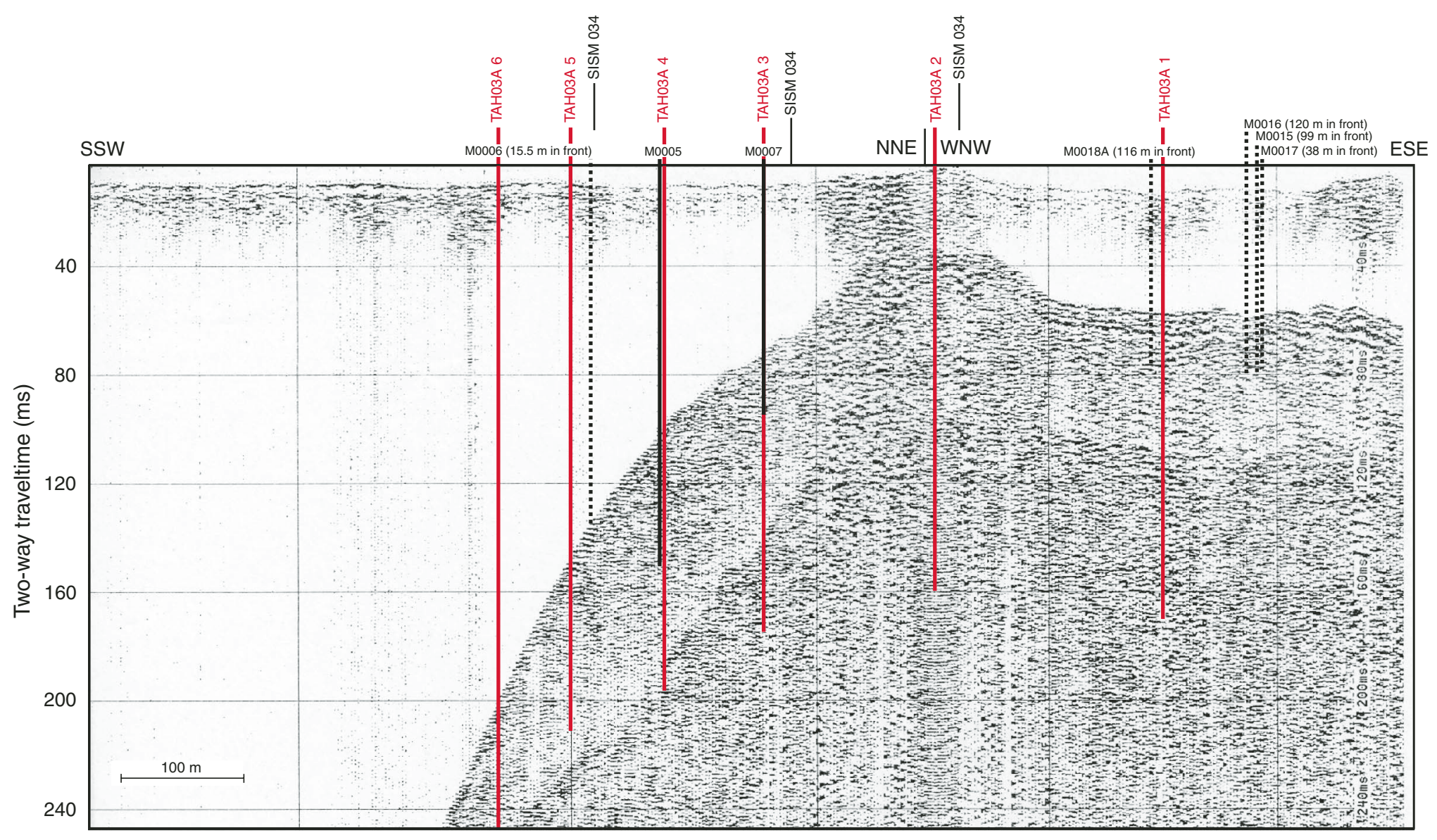

